\title{
Discovery of GLPG2451, a Novel, Once Daily Potentiator for the Treatment of Cystic Fibrosis.
}

Steven E. Van der Plast*, Hans Kelgtermanst, Oscar Mammolitit, Christel Menett, Giovanni Tricaricot, Ann De Blieckt, Caroline Joannesset, Tom De Munckt, Dominique Lambint, Marlon Cowart $\|$, Sebastien Dropsitt, Sebastien L. X. Martinat, Maarten Gees, Anne-Sophie Wesse, Katja Conrath+*, Martin Andrewst

†Galapagos NV, Generaal De Wittelaan L11 A3, 2800 Mechelen, Belgium ‡Galapagos SASU, 102 avenue Gaston Roussel, 93230 Romainville, France "Abbvie, Discovery Chemistry and Technology, North Chicago, IL, United States

\section{Content of supporting information}

Conformational modelling of 9 in the gas phase $\quad$ S2

Experimental procedures and characterisation of representative compounds $\quad$ S2

HPLC traces of lead compounds 10 and 13 
Conformational modelling of 9 in the gas phase.
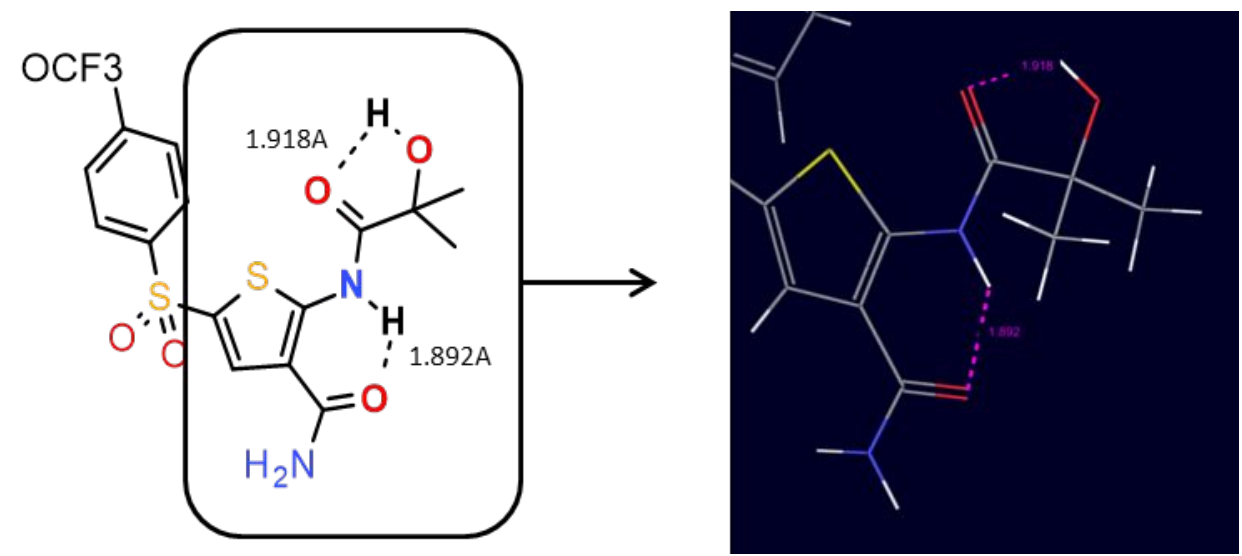

Internal $\mathrm{H}$ bonds are represented with a dotted line. Calculated distances (Angstrom) are depicted in the cartoon.

\section{Experimental procedures and characterisation of representative compounds.}

4-Carbamoyl-5-[1H-Pyrazole-3-carbonyl)amino]-thiophene-2-sulfonylchloride (41)

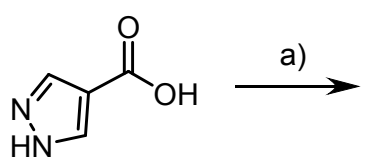

38<smiles>O=C(Cl)c1cn[nH]c1</smiles>

39
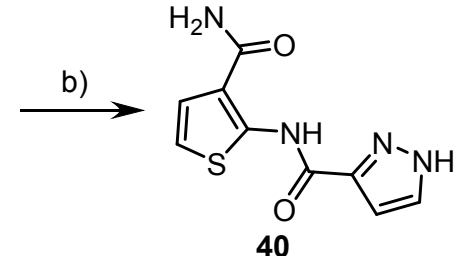

c)<smiles>NC(=O)c1cc(S(=O)(=O)Cl)sc1NC(=O)c1cc[nH]n1</smiles>

Step a): 1H-Pyrazole-3-carbonyl chloride (39)

To a solution of 1H-pyrazole-3-carboxylic acid (38, $560 \mathrm{mg}, 5 \mathrm{mmol})$ in DCM (20 mL) were added thionyl chloride $(1.80 \mathrm{~mL}, 25 \mathrm{mmol})$ and dry DMF (few drops). The reaction mixture was heated at $60^{\circ} \mathrm{C}$ overnight, cooled to room temperature and concentrated to dryness to afford the title compound 39 .

Step b): 1H-Pyrazole-3-carboxylic acid (3-carbamoyl-thiophen-2-yl)-amide (40)

To a solution of 2-amino-thiophene-3-carboxylic acid amide (570 mg, $4 \mathrm{mmol})$, pyridine $(0.5$ $\mathrm{mL}, 6 \mathrm{mmol})$ and DMAP (25 mg, $0.20 \mathrm{mmol})$ in $\mathrm{MeCN}(5 \mathrm{~mL})$ was added dropwise solution of compound $39(650 \mathrm{mg}, 5 \mathrm{mmol})$ in $\mathrm{MeCN}(5 \mathrm{~mL})$. The reaction mixture was stirred at $60^{\circ} \mathrm{C}$ for $48 \mathrm{~h}$, cooled to room temperature and quenched with saturated solution of $\mathrm{NaHCO}_{3}$. The crude mixture was partially concentrated and filtered. The collected solid was dried in vacuum oven to afford the title compound 40. LC-MS: $\mathrm{m} / \mathrm{z}=237[\mathrm{M}+\mathrm{H}]^{+}$. 
Step c): 4-Carbamoyl-5-[1H-Pyrazole-3-carbonyl)amino]-thiophene-2-sulfonylchloride (41)

To neat $\mathrm{ClSO}_{3} \mathrm{H}(1.0 \mathrm{~mL}, 15.0 \mathrm{mmol})$ was added portion wise compound 40 (355 mg, 1.5 mmol) at $0{ }^{\circ} \mathrm{C}$. The resulting mixture was stirred at $40{ }^{\circ} \mathrm{C}$ until full conversion (monitored by LC-MS). The reaction mixture was cooled to room temperature, diluted with EtOAc and poured into a mixture of ice and water. The crude mixture was extracted with EtOAc. The combined organic layers were dried over $\mathrm{MgSO}_{4}$, filtered and concentrated to dryness to afford the title compound 41 (440 mg, 87\% yield). LC-MS: m/z=335[M+H]+.

\section{N-(5-(N-benzyl-N-methylsulfamoyl)-3-carbamoylthiophen-2-yl)-1H-pyrazole-3- carboxamide (4)}<smiles>CN(Cc1ccccc1)S(=O)(=O)c1cc(C(N)=O)c(NC(=O)c2cc[nH]n2)s1</smiles>

To a suspension of compound 41 (1.3 mmol, $440 \mathrm{mg})$ in DCM (5 mL) was added a solution of pyridine (1.95 mmol, $0.16 \mathrm{~mL})$ and N-methylbenzylamine (1.6 mmol, $0.2 \mathrm{~mL})$ in DCM (3 mL). The reaction mixture was stirred at room temperature for $2.5 \mathrm{~h}$, diluted with DCM and washed with saturated solution of $\mathrm{NaHCO}_{3}$. The organic layer was dried over $\mathrm{MgSO}_{4}$, filtered and concentrated. The crude residue was purified by preparative HPLC to afford the title compound 4 (110 mg, $20 \%$ yield). ${ }^{1} \mathrm{H}$ NMR (400 MHz, DMSO- $\left.d_{6}\right) \delta 13.72(\mathrm{t}, 1 \mathrm{H}), 13.33(\mathrm{~s}, 1 \mathrm{H}), 8.21$ $(\mathrm{d}, 2 \mathrm{H}), 8.01(\mathrm{dd}, 1 \mathrm{H}), 7.78(\mathrm{~s}, 1 \mathrm{H}), 7.44-7.28(\mathrm{~m}, 6 \mathrm{H}), 6.90(\mathrm{dd}, 1 \mathrm{H}), 4.17(\mathrm{~s}, 2 \mathrm{H}), 2.62$ (s, 3H). LC-MS: $\mathrm{m} / \mathrm{z}=420.0[\mathrm{M}+\mathrm{H}]^{+}$.

\section{5-acetylamino-4-carbamoyl-thiophene-2-sulfonylchloride (43)}

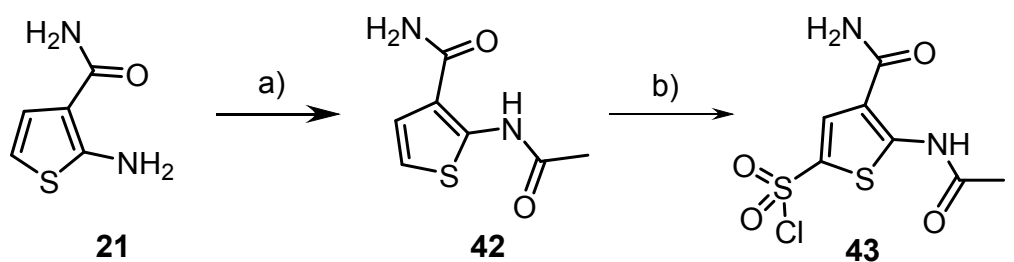

Step a): 2-acetylamino-thiophene-3-carboxylic acid amide (42)

A solution of 2-amino-thiophene-3-carboxylic acid amide 21 (20.3 g, $143 \mathrm{mmol})$ in dry pyridine $(150 \mathrm{~mL})$ was added dropwise acetylchloride $(11 \mathrm{~mL}, 156 \mathrm{mmol})$ at $0{ }^{\circ} \mathrm{C}$. The reaction mixture was stirred at room temperature overnight, diluted with water and the resulting 
suspension was filtered. The collected solid was dried overnight in a vacuum oven at $50^{\circ} \mathrm{C}$ to afford the compound 42 (19.7 g, 76\% yield). LC-MS: m/z $=185[\mathrm{M}+\mathrm{H}]^{+}$.

$+$

Step b): 5-acetylamino-4-carbamoyl-thiophene-2-sulfonylchloride (43)

To neat $\mathrm{ClSO}_{3} \mathrm{H}(29 \mathrm{~mL}, 440 \mathrm{mmol})$ was added portion wise compound $42(8.1 \mathrm{~g}, 44 \mathrm{mmol})$ at $0{ }^{\circ} \mathrm{C}$. The resulting mixture was stirred at $50{ }^{\circ} \mathrm{C}$ for $3 \mathrm{~h}$. The reaction mixture was cooled to room temperature, diluted with EtOAc and poured into a mixture of ice and water. The crude mixture was extracted with EtOAc. The combined organic layers were dried over $\mathrm{MgSO}_{4}$, filtered and concentrated to dryness to afford the title compound $\mathbf{4 3}$ ( $4.5 \mathrm{~g}, 42 \%$ yield).

\section{N-[3-carbamoyl-5-(1-piperidylsulfonyl)-2-thienyl]-1H-pyrazole-3-carboxamide (5)}

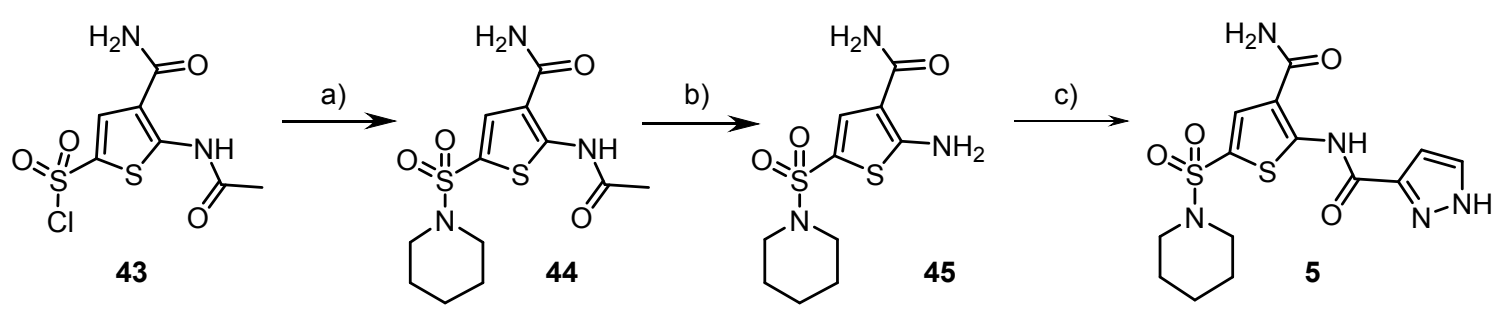

Step a): 2-acetamido-5-(1-piperidylsulfonyl)thiophene-3-carboxamide (44)

To a suspension of compound $\mathbf{4 3}$ (14.1 mmol, $4.0 \mathrm{~g})$ in DCM (50 mL) were added pyridine $(28.2 \mathrm{mmol}, 2.3 \mathrm{~mL})$ and piperidine $(28.2 \mathrm{mmol}, 2.8 \mathrm{~mL})$. The reaction mixture was diluted with 1,4-dioxane $(6 \mathrm{~mL})$ and stirred at room temperature for $1 \mathrm{~h}$. The crude mixture was diluted with DCM and quenched with saturated solution of $\mathrm{NaHCO}_{3}$. The suspension was filtered and the collected solid was washed with water and $\mathrm{Et}_{2} \mathrm{O}$ to afford the compound $44(3.0 \mathrm{~g}, 64 \%$ yield). LC-MS: $\mathrm{m} / \mathrm{z}=332[\mathrm{M}+\mathrm{H}]^{+}$.

Step b): 2-amino-5-(1-piperidylsulfonyl)thiophene-3-carboxamide (45) A solution of compound $44(3.0 \mathrm{~g}, 9.05 \mathrm{mmol})$ in 1:1 mixture of $6 \mathrm{~N} \mathrm{HCl} / 1$,4-dioxane $(40 \mathrm{~mL})$ was stirred at $100{ }^{\circ} \mathrm{C}$ for $2 \mathrm{~h}$. The reaction mixture was concentrated to dryness. The crude residue was washed with water and dried to afford the title compound 45 ( $2.4 \mathrm{~g}, 81 \%$ yield). LC-MS: $\mathrm{m} / \mathrm{z}=290[\mathrm{M}+\mathrm{H}]^{+}$.

Step c): N-[3-carbamoyl-5-(1-piperidylsulfonyl)-2-thienyl]-1H-pyrazole-3-carboxamide (5) To a solution of compound 45 (50 mg, $0.15 \mathrm{mmol}$ ), 1H-pyrazole-3-carboxylic acid (26 mg, $0.23 \mathrm{mmol})$ and $\mathrm{Et}_{3} \mathrm{~N}(105 \mu 1,0.75 \mathrm{mmol})$ in $\mathrm{MeCN}(1 \mathrm{~mL})$ were added Mukaiyama reagent 
(2-chloro-1-methylpyridinium iodide, $59 \mathrm{mg}, 0.23 \mathrm{mmol}$ ) and DMAP (9 $\mathrm{mg}, 0.07 \mathrm{mmol})$. The reaction mixture was stirred at room temperature for $1 \mathrm{~h}$, diluted with DCM and washed with saturated solution of $\mathrm{NaHCO}_{3}$. The organic phase was concentrated and the crude residue was purified by preparative HPLC to afford the title compound 5 (13 $\mathrm{mg}, 23 \%$ yield).

1H NMR (400 MHz, DMSO-d6) $\delta 13.68$ (s, 1H), 13.30 (s, 1H), 8.16 (s, 1H), $8.11(\mathrm{~s}, 1 \mathrm{H}), 8.01$ 7.97 (m, 1H), 7.70 (s, 1H), 6.90-6.86 (m, 1H), 3.02-2.93 (m, 4H), 1.63-1.52 (m, 4H), 1.46-1.35 $(\mathrm{m}, 2 \mathrm{H}) . \mathrm{LC}-\mathrm{MS}: \mathrm{m} / \mathrm{z}=384[\mathrm{M}+\mathrm{H}]^{+}$.

\section{2-amino-5-(4-fluorophenyl)sulfonyl-thiophene-3-carboxamide (49)}

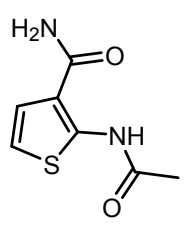

42

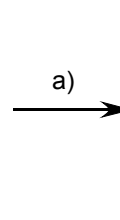

$\mathrm{Cl}$

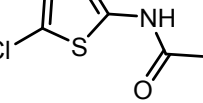

46

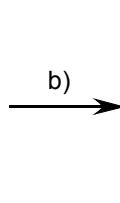<smiles>CC(=O)Nc1sc(Sc2ccc(F)cc2)cc1C(N)=O</smiles><smiles>NC(=O)c1cc(S(=O)(=O)c2ccc(F)cc2)sc1N</smiles>

Step a): 2-acetamido-5-chloro-thiophene-3-carboxamide (46)

To a solution of 2-acetamidothiophene-3-carboxamide $(2.14 \mathrm{~g}, 1.16 \mathrm{mmol})$ in $\mathrm{AcOH}(23 \mathrm{~mL})$ was added NCS $(1.71 \mathrm{~g}, 12.8 \mathrm{mmol})$. The reaction mixture was stirred at room temperature for 15h. NCS $(0.26 \mathrm{~g}, 1.92 \mathrm{mmol})$ was added and the reaction mixture was stirred at $50{ }^{\circ} \mathrm{C}$ for $1 \mathrm{~h}$. The reaction mixture was concentrated to dryness. The crude residue was triturated with EtOH and dried to afford the title compound 46 (2.37 g, 83\% yield). LC-MS: m/z $=202\left[\mathrm{M}-\mathrm{NH}_{3}\right]^{+}$.

Step b): 2-acetamido-5-(4-fluorophenyl)sulfanyl-thiophene-3-carboxamide (47)

To a solution of compound $46(437 \mathrm{mg}, 2.0 \mathrm{mmol})$ in NMP $(6 \mathrm{~mL})$ was added $\mathrm{Cs}_{2} \mathrm{CO}_{3}(1.30$ $\mathrm{g}, 4.0 \mathrm{mmol})$ and 4-fluorothiophenol $(235 \mu \mathrm{l}, 2.20 \mathrm{mmol})$. The reaction mixture was stirred in sealed tube at $145{ }^{\circ} \mathrm{C}$ for $1 \mathrm{~h}$. The mixture was cooled to room temperature, diluted with water and extracted with EtOAc. The combined organic layers were dried over $\mathrm{MgSO}_{4}$, filtered and concentrated to dryness to afford the title compound 47. LC-MS: $\mathrm{m} / \mathrm{z}=311[\mathrm{M}+\mathrm{H}]^{+}$.

$\underline{\text { Step c): 2-acetamido-5-(4-fluorophenyl)sulfonyl-thiophene-3-carboxamide (48) }}$ 
To a solution of compound $47(989 \mathrm{mg}, 3.19 \mathrm{mmol})$ in $\mathrm{AcOH}(10 \mathrm{~mL})$ was added $\mathrm{H}_{2} \mathrm{O}_{2}(35 \%$ in water, $0.9 \mathrm{~mL}, 10.26 \mathrm{mmol}$ ). The reaction mixture was stirred in sealed tube at $60{ }^{\circ} \mathrm{C}$ for 4 h. The mixture was cooled to room temperature, diluted with DCM and washed saturated solution of $\mathrm{NaHCO}_{3}$. The organic layer was dried over $\mathrm{MgSO}_{4}$, filtered and concentrated to dryness to afford the title compound 48 (2.6 g, 81\% yield). LC-MS: m/z=343 [M+H] .

Step d): 2-amino-5-(4-fluorophenyl)sulfonyl-thiophene-3-carboxamide (49)

To a solution of compound $48(883 \mathrm{mg}, 2.58 \mathrm{mmol})$ in a mixture of water $(3.9 \mathrm{~mL})$ and 1,4dioxane $(7.7 \mathrm{~mL})$ was added $12 \mathrm{~N} \mathrm{HCl}(3.9 \mathrm{~mL}, 8.70 \mathrm{~mol})$. The reaction mixture was stirred in sealed tube at $100{ }^{\circ} \mathrm{C}$ for $2 \mathrm{~h}$. The mixture was cooled to room temperature and concentrated to dryness. The crude residue was suspended in a mixture of water/EtOAc, neutralized to $\mathrm{pH} 7$ and extracted with EtOAc. The combined organic layers were dried over $\mathrm{MgSO}_{4}$, filtered and concentrated to dryness to afford the title compound 49 (444 mg, 57\% yield). LC-MS: m/z = $301[\mathrm{M}+\mathrm{H}]^{+}$.

\section{N-[3-carbamoyl-5-(4-fluorophenyl)sulfonyl-2-thienyl]-1H-pyrazole-3-carboxamide (6)}<smiles>NC(=O)c1cc(S(=O)(=O)c2ccc(F)cc2)sc1NC(=O)c1cc[nH]n1</smiles>

To a solution of compound 49 (100 mg, $0.333 \mathrm{mmol})$, 1H-pyrazole-3-carboxylic acid (49 $\mathrm{mg}$, $0.433 \mathrm{mmol})$ and $\mathrm{Et}_{3} \mathrm{~N}(100 \mathrm{mg}, 0.333 \mathrm{mmol})$ in $\mathrm{MeCN}(4 \mathrm{~mL})$ were added Mukaiyama reagent (2-chloro-1-methylpyridinium iodide, $109 \mathrm{mg}, 0.433 \mathrm{mmol}$ ) and DMAP (8 mg, $0.07 \mathrm{mmol}$ ). The reaction mixture was stirred at $60{ }^{\circ} \mathrm{C}$ for $15 \mathrm{~h}$, cooled to room temperature, diluted with DCM and washed with saturated solution of $\mathrm{NaHCO}_{3}$. The organic phase was concentrated and the crude residue was purified by preparative HPLC to afford the title compound 6 (40 mg, 30\% yield). ${ }^{1} \mathrm{H}$ NMR (400 MHz, DMSO- $d_{6}$ ) $\delta 13.73(\mathrm{~s}, 1 \mathrm{H}), 13.31(\mathrm{~s}, 1 \mathrm{H}), 8.37(\mathrm{~s}, 1 \mathrm{H}), 8.17$ $(\mathrm{s}, 1 \mathrm{H}), 8.07-7.97(\mathrm{~m}, 3 \mathrm{H}), 7.78(\mathrm{~s}, 1 \mathrm{H}), 7.56-7.44(\mathrm{~m}, 2 \mathrm{H}), 6.88(\mathrm{t}, 1 \mathrm{H}) . \mathrm{LC}-\mathrm{MS}: \mathrm{m} / \mathrm{z}=395$ $[\mathrm{M}+\mathrm{H}]^{+}$. 


\section{2-(2,2-dimethylpropanoylamino)-5-(4-fluorophenyl)sulfonyl-thiophene-3-carboxamide}

(7)

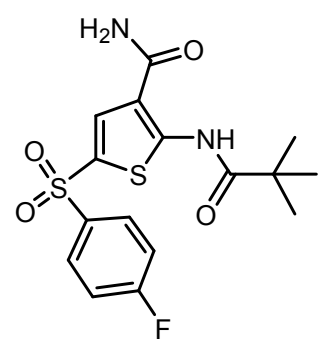

To a solution of compound 49 (100 $\mathrm{mg}, 0.333 \mathrm{mmol})$, pivalic acid (44 $\mathrm{mg}, 0.433 \mathrm{mmol})$ and $\mathrm{Et}_{3} \mathrm{~N}(186 \mu 1,1.333 \mathrm{mmol})$ in $\mathrm{MeCN}(4 \mathrm{~mL})$ were added Mukaiyama reagent (2-chloro-1methylpyridinium iodide, $109 \mathrm{mg}, 0.433 \mathrm{mmol}$ ) and DMAP ( $8 \mathrm{mg}, 0.07 \mathrm{mmol}$ ). The reaction mixture was stirred at $60{ }^{\circ} \mathrm{C}$ for $15 \mathrm{~h}$, cooled to room temperature, diluted with DCM and washed with saturated solution of $\mathrm{NaHCO}_{3}$. The organic phase was concentrated and the crude residue was purified by preparative HPLC to afford the title compound 7 ( $32 \mathrm{mg}, 25 \%$ yield). ${ }^{1} \mathrm{H}$ NMR (400 MHz, DMSO-d6) $\delta$ ppm 12.91 (s, 1H), 8.34 (s, 1H), 8.22 (s, 1H), 8.04 - 7.94 $(\mathrm{m}, 2 \mathrm{H}), 7.84(\mathrm{~s}, 1 \mathrm{H}), 7.55-7.44(\mathrm{~m}, 2 \mathrm{H}), 1.23(\mathrm{~s}, 9 \mathrm{H}) . \mathrm{LC}-\mathrm{MS}: \mathrm{m} / \mathrm{z}=385[\mathrm{M}+\mathrm{H}]^{+}$.

\section{5-(4-fluorophenyl)sulfonyl-2-[(1-hydroxycyclopropanecarbonyl)amino]thiophene-3- carboxamide (8)}

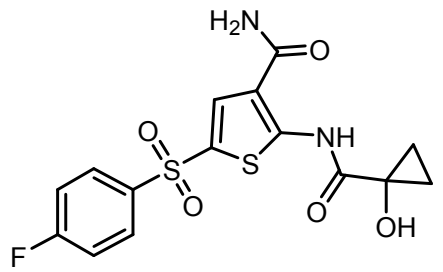

To a solution of compound 49 (100 mg, $0.333 \mathrm{mmol}), 1$-(acetyloxy)cyclopropane-1-carboxylic acid $(60 \mathrm{mg}, 0.42 \mathrm{mmol})$ and $\mathrm{Et}_{3} \mathrm{~N}(186 \mu 1,1.333 \mathrm{mmol})$ in $\mathrm{MeCN}(4 \mathrm{~mL})$ were added Mukaiyama reagent (2-chloro-1-methylpyridinium iodide, $117 \mathrm{mg}, 0.46 \mathrm{mmol}$ ) and DMAP (12 mg, $0.1 \mathrm{mmol})$. The reaction mixture was stirred in sealed tube at $50{ }^{\circ} \mathrm{C}$ for $1 \mathrm{~h}$. The reaction mixture was cooled to room temperature and partitioned between DCM and water. The organic layer was dried over $\mathrm{MgSO}_{4}$, filtered and concentrated to dryness. The crude residue was stirred in $7 \mathrm{~N} \mathrm{NH} \mathrm{MeOH}$ solution $(10 \mathrm{~mL})$ at room temperature for $48 \mathrm{~h}$. The mixture was concentrated to dryness and the crude residue was purified by preparative HPLC to afford the title compound 8 (20 mg, 18\% yield). ${ }^{1} \mathrm{H}$ NMR $\delta(\mathrm{ppm})\left(\mathrm{DMSO}_{6}\right.$ ): 13.15 (s, $\left.1 \mathrm{H}\right), 8.34$ (s br, $\left.1 \mathrm{H}\right), 8.14$ (s, 1 H), 7.99 (dd, 2 H), 7.75 (s, 1 H), 7.49 (t, 2 H), 7.00 (s, 1 H), 1.21 (m, 2 H), 1.11 (m, 2 H). LCMS: $\mathrm{m} / \mathrm{z}=385[\mathrm{M}+\mathrm{H}]^{+}$. 


\section{5-(4-fluorophenyl)sulfonyl-2-[(2-hydroxy-2-methyl-propanoyl)amino]thiophene-3- carboxamide (9)}<smiles>CC(C)(O)C(=O)Nc1sc(S(=O)(=O)c2ccc(F)cc2)cc1C(N)=O</smiles>

To a solution of compound $49(150 \mathrm{mg}, 0.499 \mathrm{mmol})$ in DCM $(1.5 \mathrm{~mL})$ was added 2acetoxyisobutyryl chloride (90 mg, $0.549 \mathrm{mmol})$ and $\mathrm{Et}_{3} \mathrm{~N}(133 \mu 1,0.749 \mathrm{mmol})$. The reaction mixture was stirred in sealed vial at $60^{\circ} \mathrm{C}$ for $15 \mathrm{~h}$. The reaction mixture was cooled to room temperature and portioned between DCM and water. The organic layer was dried over $\mathrm{MgSO}_{4}$, filtered and concentrated to dryness. The crude residue was dissolved in $\mathrm{MeOH}(2.6 \mathrm{~mL})$ and $\mathrm{K}_{2} \mathrm{CO}_{3}(177 \mathrm{mg}, 1.28 \mathrm{mmol})$ was added. The mixture was stirred at $65{ }^{\circ} \mathrm{C}$ for $15 \mathrm{~h}$, cooled to room temperature and portioned between EtOAc and water. The organic layer was dried over $\mathrm{MgSO}_{4}$, filtered and concentrated to dryness. The crude residue was purified by preparative HPLC to afford the title compound 9 (20 mg, 15\% yield). ${ }^{1} \mathrm{H}$ NMR (400 MHz, DMSO- $\left.d_{6}\right) \delta$ $12.94(\mathrm{~s}, 1 \mathrm{H}), 8.35(\mathrm{~s}, 1 \mathrm{H}), 8.14(\mathrm{~s}, 1 \mathrm{H}), 8.05-7.95(\mathrm{~m}, 2 \mathrm{H}), 7.72(\mathrm{~s}, 1 \mathrm{H}), 7.56-7.44(\mathrm{~m}, 2 \mathrm{H})$, $6.15(\mathrm{~s}, 1 \mathrm{H}), 1.34(\mathrm{~s}, 7 \mathrm{H}), 1.23(\mathrm{~s}, 1 \mathrm{H}) . \mathrm{LC}-\mathrm{MS}: \mathrm{m} / \mathrm{z}=421[\mathrm{M}+\mathrm{H}]^{+}$.

\section{2-[(2-hydroxy-2-methyl-propanoyl)amino]-5-[4-(trifluoromethoxy)phenyl]sulfonyl-}

\section{thiophene-3-carboxamide (10)}

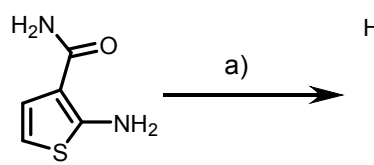

21

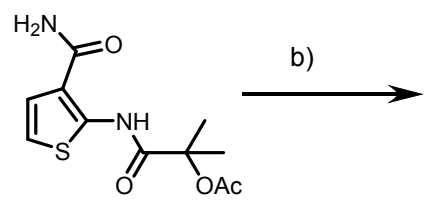

22

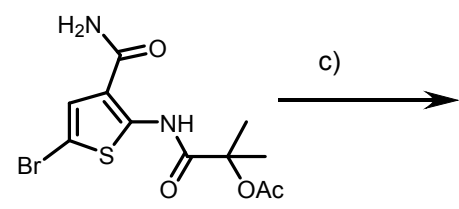

23<smiles>CC(C)(O)C(=O)Nc1sc(Sc2ccc(OC(F)(F)F)cc2)cc1C(N)=O</smiles>
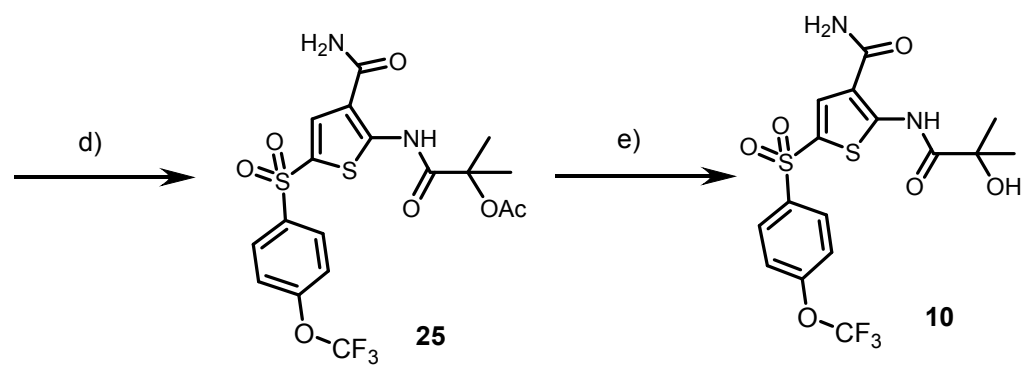

Step a): [2-[(3-carbamoyl-2-thienyl)amino]-1,1-dimethyl-2-oxo-ethyl] acetate (22)

To a solution of 2-aminothiophene-3-carboxamide 21 (3.9 g, $27.4 \mathrm{mmol})$ in DCM (45 mL) was added pyridine $(3.77 \mathrm{~mL}, 45.8 \mathrm{mmol})$. The mixture was cooled to $0{ }^{\circ} \mathrm{C}$ and a solution of 2acetoxyisobutyryl chloride $(5 \mathrm{~g}, 30.5 \mathrm{mmol})$ in DCM $(25 \mathrm{~mL})$ was added dropwise. The 
reaction mixture was stirred at room temperature for $2 \mathrm{~h}$, quenched with water and extracted with DCM. The combined organic layers were dried over $\mathrm{Na}_{2} \mathrm{SO}_{4}$, filtered, and concentrated to dryness. The crude residue was triturated with water and dried to afford the title compound 22 (6.89 g, 93\% yield). LC-MS: $\mathrm{m} / \mathrm{z}=271[\mathrm{M}+\mathrm{H}]^{+}$.

Step b): [2-[(5-bromo-3-carbamoyl-2-thienyl)amino]-1,1-dimethyl-2-oxo-ethyl] acetate (23) To a solution of compound 22 (4.05 g, $15.0 \mathrm{mmol})$ in AcOH $(60 \mathrm{~mL})$ was added dropwise NBS (2.8 $\mathrm{g}, 15.75 \mathrm{mmol})$. The reaction mixture was stirred at room temperature for $1 \mathrm{~h}$, quenched with water and extracted with EtOAc. The combined organic layers were washed with saturated solution of $\mathrm{Na}_{2} \mathrm{CO}_{3}$, dried over $\mathrm{Na}_{2} \mathrm{SO}_{4}$, filtered and concentrated to afford the title compound 23 (5.12 g, 98\% yield). LC-MS: m/z = 351[M+H $]^{+}$.

Step c): [2-[[3-carbamoyl-5-[4-(trifluoromethoxy)phenyl] sulfanyl-2-thienyl]amino]-1,1dimethyl-2-oxo-ethyl] acetate (24)

To a solution of compound $23(250 \mathrm{mg}, 0.72 \mathrm{mmol})$ in dioxane $(3 \mathrm{ml})$ were added trifluoromethoxybenzenethiol (181 mg, $0.93 \mathrm{mmol}), \operatorname{Pd}(\mathrm{OAc})_{2}(8.1 \mathrm{mg}, 0.036 \mathrm{mmol})$, DiPPF $(9.7 \mathrm{mg}, 0.043 \mathrm{mmol})$ and $\mathrm{NaOtBu}(83 \mathrm{mg}, 0.86 \mathrm{mmol})$. The reaction mixture was flushed with nitrogen, the vial was sealed and the mixture was stirred at $160{ }^{\circ} \mathrm{C}$ for $16 \mathrm{~h}$. The crude mixture was cooled to room temperature, filtered through a silica plug and washed with EtOAc. The filtrate was concentrated to afford the title compound 24 . LC-MS: $\mathrm{m} / \mathrm{z}=463[\mathrm{M}+\mathrm{H}]^{+}$.

Step d): [2-[[3-carbamoyl-5-[4-(trifluoromethoxy)phenyl] sulfonyl-2-thienyl]amino]-1,1dimethyl-2-oxo-ethyl] acetate (25)

To a solution of compound $24(330 \mathrm{mg}, 0.72 \mathrm{mmol})$ in $\mathrm{AcOH}(10 \mathrm{~mL})$ was added $\mathrm{H}_{2} \mathrm{O}_{2}(35 \%$ in water, $0.25 \mathrm{~mL}, 2.88 \mathrm{mmol}$ ). The reaction mixture was stirred in sealed tube at $60{ }^{\circ} \mathrm{C}$ for 4 h. The mixture was cooled to room temperature, diluted with water and extracted with EtOAc. The combined organic layers were washed with saturated solution of $\mathrm{Na}_{2} \mathrm{CO}_{3}$, dried over $\mathrm{MgSO}_{4}$, filtered and concentrated to dryness to afford the title compound 25 . LC-MS: $\mathrm{m} / \mathrm{z}=$ $495[\mathrm{M}+\mathrm{H}]^{+}$.

Step e): 2-[(2-hydroxy-2-methyl-propanoyl)amino]-5-[4-(trifluoromethoxy)phenyl]sulfonylthiophene-3-carboxamide (10)

To a solution of compound 25 (360 mg, $0.72 \mathrm{mmol})$ in $\mathrm{MeOH}(10 \mathrm{~mL})$ was added $\mathrm{K}_{2} \mathrm{CO}_{3}(200$ $\mathrm{mg}, 1.44 \mathrm{mmol})$. The reaction mixture was stirred at $60{ }^{\circ} \mathrm{C}$ for $16 \mathrm{~h}$, cooled to room 
temperature, quenched with water and extracted with EtOAc. The combined organic layers were dried over $\mathrm{MgSO}_{4}$, filtered and concentrated to dryness. The crude residue was purified by preparative HPLC to afford the title compound $\mathbf{1 0}$ (22 $\mathrm{mg}, 8 \%$ yield). LC-MS: m/z = $453[\mathrm{M}+\mathrm{H}]^{+}$.

\section{3-amino-N-(2-hydroxy-2-methyl-propyl)-5-[4-(trifluoromethoxy)phenyl]sulfonyl- pyridine-2-carboxamide (11)}<smiles>CC(C)(O)CNC(=O)c1ncc(S(=O)(=O)c2ccc(OC(F)(F)F)cc2)cc1N</smiles>

To a solution of compound $28(50 \mathrm{mg}, 0.14 \mathrm{mmol})$ in DMA $(550 \mu \mathrm{L})$ were added 1-amino-2methyl-propan-2-ol (12 mg, $0.14 \mathrm{mmol}), \mathrm{HATU}(52 \mathrm{mg}, 0.14 \mathrm{mmol})$ and $\mathrm{Et}_{3} \mathrm{~N}(39 \mu \mathrm{L}, 0.28$ mmol) The reaction mixture was stirred at room temperature for $15 \mathrm{~h}$, diluted with water and extracted with EtOAc. The combined organic layers were then dried over $\mathrm{MgSO}_{4}$, filtered and concentrated. The crude residue was purified by preparative HPLC to afford the title compound 11 (10 mg, 17\% yield). ${ }^{1} \mathrm{H}$ NMR (400 MHz, DMSO-d6) $\delta$ ppm 8.39 (t, $\left.1 \mathrm{H}\right), 8.24$ (d, $\left.1 \mathrm{H}\right)$, 8.13 (d, 2 H), 7.74 (d, 1 H), 7.65 (d, 2 H), 7.27 (s br, 5 H), 4.65 (s, 1 H), 3.21 (d, 2 H), 1.07 (s, $6 \mathrm{H})$. LC-MS: $\mathrm{m} / \mathrm{z}=434[\mathrm{M}+\mathrm{H}]^{+}$

\section{3-amino-N-(3,3,3-trifluoro-2-hydroxy-propyl)-5-[4-(trifluoromethoxy)phenyl]sulfonyl- pyridine-2-carboxamide (12)}<smiles>Nc1cc(S(=O)(=O)c2ccc(OC(F)(F)F)cc2)cnc1C(=O)NCC(O)C(F)(F)F</smiles>

To a solution of compound $28(50 \mathrm{mg}, 0.14 \mathrm{mmol})$ in DMA $(550 \mu \mathrm{L})$ were added 3-amino1,1,1-trifluoro-propan-2-ol (18 mg, $0.14 \mathrm{mmol}), \mathrm{HATU}(52 \mathrm{mg}, 0.14 \mathrm{mmol})$ and $\mathrm{Et}_{3} \mathrm{~N}(39 \mu \mathrm{L}$, $0.28 \mathrm{mmol}$ ) The reaction mixture was stirred at room temperature for $15 \mathrm{~h}$, diluted with water and extracted with EtOAc. The combined organic layers were then dried over $\mathrm{MgSO}_{4}$, filtered and concentrated. The crude residue was purified by preparative HPLC to afford the title compound 22 (12 mg, 18\% yield). 1H NMR (400 MHz, DMSO-d6) $\delta$ ppm 8.39 (t, $1 \mathrm{H}), 8.24$ 
$(\mathrm{d}, 1 \mathrm{H}), 8.13(\mathrm{~d}, 2 \mathrm{H}), 7.74(\mathrm{~d}, 1 \mathrm{H}), 7.65(\mathrm{~d}, 2 \mathrm{H}), 7.27(\mathrm{~s}, 2 \mathrm{H}), 6.44(\mathrm{~d}, 1 \mathrm{H}), 4.20(\mathrm{~m}, 1 \mathrm{H})$, 3.57 (m, $1 \mathrm{H}), 3.38$ (m, $1 \mathrm{H})$. LC-MS: m/z $=474[\mathrm{M}+\mathrm{H}]^{+}$

\section{3-amino-N-[(1-hydroxycyclopropyl)methyl]-5-[4-(trifluoromethoxy)phenyl]sulfonyl- pyridine-2-carboxamide (14)}<smiles>Nc1cc(S(=O)(=O)c2ccc(OC(F)(F)F)cc2)cnc1C(=O)NCC1(O)CC1</smiles>

To a solution of compound $28(50 \mathrm{mg}, 0.14 \mathrm{mmol})$ in DMA $(550 \mu \mathrm{L})$ were added 1(aminomethyl)cyclopropanol (12 mg, $0.14 \mathrm{mmol})$, HATU (52 mg, $0.14 \mathrm{mmol}$ ) and $\mathrm{Et}_{3} \mathrm{~N}$ (39 $\mu \mathrm{L}, 0.28 \mathrm{mmol}$ ) The reaction mixture was stirred at room temperature for $15 \mathrm{~h}$, diluted with water and extracted with EtOAc. The combined organic layers were then dried over $\mathrm{MgSO}_{4}$, filtered and concentrated. The crude residue was purified by preparative HPLC to afford the title compound 14 (13 mg, 22\% yield). ${ }^{1} \mathrm{H}$ NMR (400 MHz, DMSO-d6) $\delta$ ppm 8.56 (t, 1H), $8.25(\mathrm{~d}, 1 \mathrm{H}), 8.14(\mathrm{~d}, 2 \mathrm{H}), 7.74(\mathrm{~d}, 1 \mathrm{H}), 7.66(\mathrm{~d}, 2 \mathrm{H}), 7.28(\mathrm{~s}, 2 \mathrm{H}), 5.49(\mathrm{~s}, 1 \mathrm{H}), 3.37(\mathrm{~d}, 2 \mathrm{H})$, $0.60-0.48(\mathrm{~m}, 4 \mathrm{H})$ LC-MS: $\mathrm{m} / \mathrm{z}=432[\mathrm{M}+\mathrm{H}]^{+}$

\section{3-Amino-5-(4-fluoro-benzenesulfonyl)-pyridine-2-carboxylic acid (32)}<smiles>CC(C)C</smiles>

26<smiles>Nc1cc(Sc2ccc(F)cc2)cnc1C(=O)O</smiles>

31

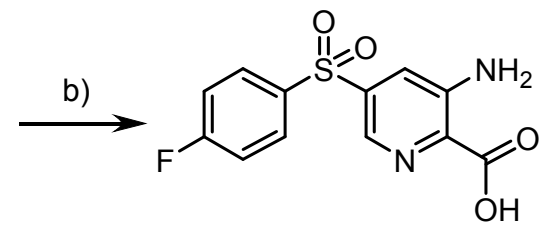

32

Step a): 3-Amino-5-(4-fluoro-phenylsulfanyl)-pyridine-2-carboxylic acid (31):

To a solution of 3-amino-5-bromo-pyridine-2-carboxylic acid (26) (13 g, $60 \mathrm{mmol}$ ) in DMA $(90 \mathrm{~mL})$ were added 4-fluoro-benzenethiol (7.68 g, $60 \mathrm{mmol})$ and DBU $(9.0 \mathrm{~mL}, 60 \mathrm{mmol})$. The reaction mixture was stirred at $140{ }^{\circ} \mathrm{C}$ for $50 \mathrm{~min}$ in microwave reactor. The crude mixture was cooled to room temperature and diluted with a $1 \% \mathrm{AcOH}$ solution in water. The resulting precipitate was collected by filtration, washed with petroleum ether and dried in a vacuum oven to afford the tittle compound 31 (10.6 g, 67\% yield). LC-MS: m/z $=265[\mathrm{M}+\mathrm{H}]^{+}$

Step b): 3-Amino-5-(4-fluoro-benzenesulfonyl)-pyridine-2-carboxylic acid (32): 
To a solution of compound $31(10.6 \mathrm{~g}, 40.2 \mathrm{mmol})$ in TFA $(110 \mathrm{~mL})$ was added $\mathrm{H}_{2} \mathrm{O}_{2}(13.7$ $\mathrm{mL}, 160 \mathrm{mmol}$ ) at $0{ }^{\circ} \mathrm{C}$. The reaction mixture was stirred at $0^{\circ} \mathrm{C}$ for $30 \mathrm{~min}$ and then at room temperature until full conversion (monitored by LC-MS). The crude mixture was diluted with water while stirring at $0^{\circ} \mathrm{C}$. The resulting precipitate was collected by filtration, washed with water and dried in a vacuum oven to afford the tittle compound $\mathbf{3 2}\left(9.52 \mathrm{~g}, 80 \%\right.$ yield). ${ }^{1} \mathrm{H}$ NMR (400 MHz, DMSO-d6) $\delta$ ppm 12.98 (s, 1H), 8.25 (d, 1H), 8.08 (dd, 2H), 7.78 (d, 1H), 7.53 (dd, 2H), 7.07 (s, 1H). LC-MS: m/z = $297[\mathrm{M}+\mathrm{H}]^{+}$

\section{3-Amino-5-(4-fluorophenyl)sulfonyl-N-(3,3,3-trifluoro-2-hydroxy-propyl)pyridine-2- carboxamide (15)}<smiles>Nc1cc(S(=O)(=O)c2ccc(F)cc2)cnc1C(=O)NCC(O)(F)F</smiles>

To a solution of compound 32 (4.44 g, $15 \mathrm{mmol})$ in NMP (75 mL) were added (2R)-3-amino1,1,1-trifluoro-propan-2-ol (2.48 g, $15 \mathrm{mmol})$, HATU (5.70 g, $15 \mathrm{mmol})$ and $\mathrm{Et}_{3} \mathrm{~N}(4.18 \mathrm{~mL}$, $30 \mathrm{mmol}$ ) The reaction mixture was stirred for $30 \mathrm{~min}$, diluted with water and extracted with EtOAc. The combined organic layers were then dried over $\mathrm{Na}_{2} \mathrm{SO}_{4}$, filtered and concentrated. The crude residue was purified by flash chromatography, using a mixture of EtOAc/petroleum ether (ratio 1/3) to afford the title compound 15 (700 mg, 12\% yield).

${ }^{1} \mathrm{H}$ NMR (400 MHz, DMSO-d6) $\delta 8.74(1 \mathrm{H}, \mathrm{t}), 8.21$ (1 H, d), 8.07 (2 H, m), $7.73(1 \mathrm{H}, \mathrm{d})$, $7.50(2 \mathrm{H}, \mathrm{m}), 7.26(2 \mathrm{H}, \mathrm{s}, \mathrm{br}), 6.45(1 \mathrm{H}, \mathrm{d}), 4.21(1 \mathrm{H}, \mathrm{m}), 3.56(1 \mathrm{H}, \mathrm{m}), 3.38(1 \mathrm{H}, \mathrm{m})$. LCMS: $\mathrm{m} / \mathrm{z}=408[\mathrm{M}+\mathrm{H}]^{+}$

\section{3-Amino-5-(4-fluorophenyl)sulfonyl-N-methyl-N-[(2R)-3,3,3-trifluoro-2-hydroxy- propyl]pyridine-2-carboxamide (16)}<smiles>CN(CC(O)(F)F)C(=O)c1ncc(S(=O)(=O)c2ccc(F)cc2)cc1N</smiles>

To a solution of compound $32(50 \mathrm{mg}, 0.17 \mathrm{mmol})$ in DMA $(675 \mu \mathrm{L})$ were added $(2 R)-1,1,1$ trifluoro-3-(methylamino)propan-2-ol (24 mg, $0.17 \mathrm{mmol}$ ), HATU (64 mg, $0.17 \mathrm{mmol}$ ) and $\mathrm{Et}_{3} \mathrm{~N}$ (47 $\left.\mu \mathrm{L}, 0.34 \mathrm{mmol}\right)$. The reaction mixture was stirred at room temperature for $15 \mathrm{~h}$, diluted with water and extracted with EtOAc. The combined organic layers were then dried 
over $\mathrm{MgSO}_{4}$, filtered and concentrated. The crude residue was purified by preparative HPLC to afford the title compound 16 (12 mg, 17\% yield). ${ }^{1} \mathrm{H}$ NMR (400 MHz, DMSO-d6) $\delta \mathrm{ppm}$ $8.23(\mathrm{dd}, 1 \mathrm{H}), 8.06(\mathrm{dt}, 2 \mathrm{H}), 7.61(\mathrm{dd}, 1 \mathrm{H}), 7.56-7.47(\mathrm{~m}, 2 \mathrm{H}), 6.62(\mathrm{dd}, 1 \mathrm{H}), 6.04(\mathrm{~s}, 1 \mathrm{H})$, $5.97(\mathrm{~s}, 1 \mathrm{H}), 4.33(\mathrm{dd}, 1 \mathrm{H}), 3.93$ - $3.46(\mathrm{~m}, 1 \mathrm{H}), 3.47$ - $3.35(\mathrm{~m}, 1 \mathrm{H}), 3.00$ (d, 3H). LCM-MS: $\mathrm{m} / \mathrm{z}=422[\mathrm{M}+\mathrm{H}]^{+}$

\section{3-Amino-5-(4-trifluoromethyl-benzenesulfonyl)-pyridine-2-carboxylic acid (30)}<smiles>Nc1cc(Br)cnc1C(=O)O</smiles>

26

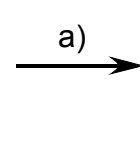<smiles>Nc1cc(Sc2ccc(C(F)(F)F)cc2)cnc1C(=O)O</smiles>

29<smiles>CC(C)CC(C)(C)C(F)(F)c1ccc(S(=O)(=O)c2cnc(C(=O)O)c(N)c2)cc1</smiles>

Step a): 3-Amino-5-(4-trifluoromethyl-phenylsulfanyl)-pyridine-2-carboxylic acid (29):

To a solution of 3-amino-5-bromo-pyridine-2-carboxylic acid (26) (3.79 g, $17.4 \mathrm{mmol})$ in DMA (15 mL) were added trifluoromethyl-benzenethiol $(4.1 \mathrm{~g}, 21 \mathrm{mmol})$ and DBU $(2.6 \mathrm{~mL}$, $17.4 \mathrm{mmol}$ ). The reaction mixture was stirred at $140{ }^{\circ} \mathrm{C}$ for $45 \mathrm{~min}$ in microwave reactor. The crude mixture was cooled to room temperature and diluted with a $1 \% \mathrm{AcOH}$ solution in water. The resulting precipitate was collected by filtration, washed with a $1 \% \mathrm{AcOH} /$ water mixture followed by with petroleum ether. Obtained solid was dried in vacuum oven to afford the tittle compound 29 (3.6 g, 65\% yield). LC-MS: m/z $=315[\mathrm{M}+\mathrm{H}]^{+}$.

Step b): 3-Amino-5-(4-trifluoromethyl-benzenesulfonyl)-pyridine-2-carboxylic acid (30):

To a solution of compound $29(5.5 \mathrm{~g}, 17.5 \mathrm{mmol})$ in TFA $(35 \mathrm{~mL})$ was added $\mathrm{H}_{2} \mathrm{O}_{2}(6 \mathrm{~mL}, 70$ mmol) at $0{ }^{\circ} \mathrm{C}$. The reaction mixture was stirred at $0^{\circ} \mathrm{C}$ until full conversion (monitored by LCMS). The crude mixture was diluted with $1 \% \mathrm{AcOH}$ solution in water while stirring at $0^{\circ} \mathrm{C}$. The resulting precipitate was collected by filtration, washed with $1 \% \mathrm{AcOH}$ solution in water and dried in a vacuum oven to afford the tittle compound 30 (4.84 g, 80\% yield). ${ }^{1} \mathrm{H}$ NMR (400 MHz, DMSO-d6) $\delta$ ppm 13.10 (s, 1H), 8.28 (d, 1H), 8.22 (d, 2H), 8.06 (d, 2H), $7.82(\mathrm{~d}, 1 \mathrm{H})$, 7.14 (s, 2H). LC-MS: m/z = $347[\mathrm{M}+\mathrm{H}]^{+}$

\section{[3-Amino-5-[4-(trifluoromethyl)phenyl]sulfonyl-2-pyridyl]-[(2S)-2-}

\section{(hydroxymethyl)pyrrolidin-1-yl]methanone (17)}


<smiles>Nc1cc(S(=O)(=O)c2ccc(F)cc2)cnc1C(=O)N1CCC[C@H]1CO</smiles>

To a solution of compound $30(50 \mathrm{mg}, 0.14 \mathrm{mmol})$ in DMA $(578 \mu \mathrm{L})$ were added $[(2 \mathrm{~S})$ pyrrolidin-2-yl]methanol (16 mg, $0.16 \mathrm{mmol})$, HATU (60 mg, $0.16 \mathrm{mmol})$ and $\mathrm{Et}_{3} \mathrm{~N}(44 \mu \mathrm{L}$, $0.32 \mathrm{mmol}$ ). The reaction mixture was stirred at room temperature for $15 \mathrm{~h}$, diluted with water and extracted with EtOAc. The combined organic layers were then dried over $\mathrm{MgSO}_{4}$, filtered and concentrated. The crude residue was purified by preparative HPLC to afford the title compound 17 ( $9 \mathrm{mg}, 15 \%$ yield).

[3-Amino-5-(4-fluorophenyl)sulfonyl-2-pyridyl]-[3-hydroxy-3-(trifluoromethyl)azetidin1-yl]methanone (18)<smiles>Nc1cc(S(=O)(=O)c2ccc(F)cc2)cnc1C(=O)N1CC(O)(C(F)(F)F)C1</smiles>

To a solution of compound $32(50 \mathrm{mg}, 0.17 \mathrm{mmol})$ in DMA $(680 \mu \mathrm{L})$ were added 3(trifluoromethyl)azetidin-3-ol (24 mg, $0.17 \mathrm{mmol})$, HATU (64mg, $0.17 \mathrm{mmol}$ ) and $\mathrm{Et}_{3} \mathrm{~N}(47$ $\mu \mathrm{L}, 0.34 \mathrm{mmol}$ ). The reaction mixture was stirred at room temperature for $15 \mathrm{~h}$, diluted with water and extracted with EtOAc. The combined organic layers were then dried over $\mathrm{MgSO}_{4}$, filtered and concentrated. The crude residue was purified by preparative HPLC to afford the title compound 18 (10 mg, 14\% yield). 1H NMR (400 MHz, DMSO-d6) $\delta$ ppm 8.20 (d, $1 \mathrm{H})$, 8.06 (m, 2 H), 7.72 (d, 1 H), 7.51 (m, 2 H), 7.44 (s, 1 H), 7.16 (s br, 2 H), 4.75 (m, 1 H), 4.50 $(\mathrm{m}, 1 \mathrm{H}), 4.24(\mathrm{~m}, 1 \mathrm{H}), 4.00(\mathrm{~m}, 1 \mathrm{H})$. LCM-MS: $\mathrm{m} / \mathrm{z}=420[\mathrm{M}+\mathrm{H}]^{+}$

\section{3-Amino-5-[2-(trifluoromethoxy)phenyl]sulfonyl-pyridine-2-carboxylic acid (34)}<smiles>CC(C)C</smiles>
26<smiles>Nc1cc(Sc2ccccc2OC(F)(F)F)cnc1C(=O)O</smiles>

33

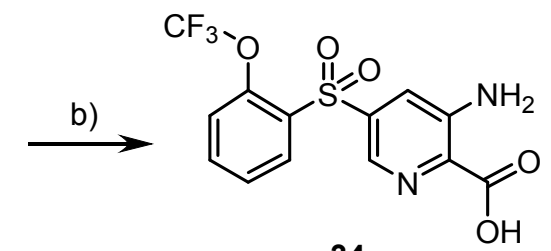

34

$\underline{\text { Step a): 3-Amino-5-(2-trifluoromethoxy-phenylsulfanyl)-pyridine-2-carboxylic acid (33) }}$ 
To a solution of 3-amino-5-bromo-pyridine-2-carboxylic acid (26) (868 $\mathrm{mg}, 4.0 \mathrm{mmol}$ ) in DMA (15 mL) were added 2-trifluoromethoxy-thiophenol (776 mg, $4.0 \mathrm{mmol}$ ) and DBU (600 $\mu \mathrm{L}, 4.0 \mathrm{mmol}$ ). The reaction mixture was stirred at $140{ }^{\circ} \mathrm{C}$ for $60 \mathrm{~min}$ in microwave reactor. The crude mixture was cooled to $0{ }^{\circ} \mathrm{C}$, diluted with water and acidified to $\mathrm{pH}=4$ with $\mathrm{AcOH}$. The resulting precipitate was collected by filtration, washed with water followed by petroleum ether. Obtained solid was dried in vacuum oven to afford the tittle compound $\mathbf{3 3}$ (3830 $\mathrm{mg}$, $83 \%$ yield). LC-MS: $\mathrm{m} / \mathrm{z}=331[\mathrm{M}+\mathrm{H}]^{+}$

Step b): 3-Amino-5-(2-trifluoromethoxy-benzenesulfonyl)-pyridine-2-carboxylic acid (34) To a solution of compound $33(830 \mathrm{mg}, 2.5 \mathrm{mmol})$ in TFA $(5 \mathrm{~mL})$ was added $\mathrm{H}_{2} \mathrm{O}_{2}(0.86 \mathrm{~mL}$, $10 \mathrm{mmol}$ ) at $0{ }^{\circ} \mathrm{C}$. The reaction mixture was stirred at room temperature overnight, poured into water and acidified to $\mathrm{pH}=4$ with $\mathrm{AcOH}$. The resulting precipitate was collected by filtration, washed with water and dried to afford the tittle compound 34 (700 mg, 77\% yield). LC-MS: $\mathrm{m} / \mathrm{z}=363[\mathrm{M}+\mathrm{H}]^{+}$

\section{3-Amino-N-[(2R)-3,3,3-trifluoro-2-hydroxy-propyl]-5-[2-}

\section{(trifluoromethoxy)phenyl]sulfonyl-pyridine-2-carboxamide (19)}<smiles>Nc1cc(S(=O)(=O)c2ccccc2OC(F)(F)F)cnc1C(=O)NC[C@H](O)C(F)(F)F</smiles>

To a solution of compound 34 (50 mg, $0.14 \mathrm{mmol})$ in DMA (550 $\mu \mathrm{L})$ were added (2R)-3amino-1,1,1-trifluoro-propan-2-ol (18 mg, $0.14 \mathrm{mmol})$, HATU (52 mg, $0.14 \mathrm{mmol}$ ) and $\mathrm{Et}_{3} \mathrm{~N}$ (39 $\mu \mathrm{L}, 0.28 \mathrm{mmol})$. The reaction mixture was stirred at room temperature for $15 \mathrm{~h}$, diluted with water and extracted with EtOAc. The combined organic layers were then dried over $\mathrm{MgSO}_{4}$, filtered and concentrated. The crude residue was purified by preparative HPLC to afford the title compound $19 \quad(9 \quad \mathrm{mg}, \quad 14 \%$ yield $)$. ${ }^{1} \mathrm{H}$ NMR (400 MHz, DMSO-d6) $\delta$ ppm 8.79 (t, $\left.1 \mathrm{H}\right), 8.25$ (m, $\left.1 \mathrm{H}\right), 8.12$ (d, $\left.1 \mathrm{H}\right), 7.92$ (m, 1 H), 7.72 (m, 2 H), 7.60 (m, 1 H), 7.30 (s br, 2 H), 6.44 (s br, 1 H), 4.22 (m, 1 H), 3.57 (m, 1 H), $3.39(\mathrm{~m}, 1 \mathrm{H})$. LCM-MS: $\mathrm{m} / \mathrm{z}=474[\mathrm{M}+\mathrm{H}]^{+}$ 
(37):<smiles>Nc1cc(Br)cnc1C(=O)O</smiles>

26

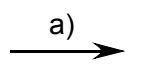<smiles>Nc1cc(Br)cnc1C(=O)NCC(O)C(F)(F)F</smiles>

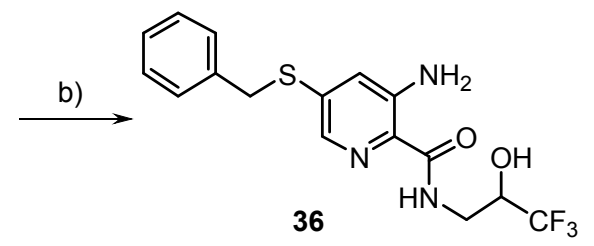<smiles>CC(Cl)(Cl)C1CCCCC1</smiles>

Step a): 33-amino-5-bromo-N-(3,3,3-trifluoro-2-hydroxy-propyl)pyridine-2-carboxamide (35) To a solution of 3-amino-5-bromopyridine-2-carboxylic acid 26 (5.1 g, $23.5 \mathrm{mmol})$ in NMP $(170 \mathrm{~mL})$ were added of HATU $(13.4 \mathrm{~g}, 35.3 \mathrm{mmol}), \mathrm{Et}_{3} \mathrm{~N}(9.8 \mathrm{~mL}, 71 \mathrm{mmol})$ and 3-amino1,1,1-trifluoro-propan-2-ol ( $\mathrm{HCl}$ salt, $5.82 \mathrm{~g}, 35.3 \mathrm{mmol}$ ). The reaction mixture was stirred at room temperature until full conversion (monitored by LC-MS). The crude mixture was diluted with water and extracted with EtOAc. The combined organic layers were washed with water, dried over $\mathrm{Na}_{2} \mathrm{SO}_{4}$, filtered and concentrated to afford the title compound $35(6.17 \mathrm{~g}, 80 \%)$. LC-MS: $\mathrm{m} / \mathrm{z}=329[\mathrm{M}+\mathrm{H}]+$

Step b): 3-Amino-5-benzylsulfanyl-N-(3,3,3-trifluoro-2-hydroxy-propyl)pyridine-2carboxamide (36)

To a solution of compound $35(2.9 \mathrm{~g}, 8.87 \mathrm{mmol})$ in toluene $(5 \mathrm{ml})$ were added benzyl mercaptan (1.25 mL, $10.6 \mathrm{mmol}), \mathrm{Pd}_{2}(\mathrm{dba})_{3}(247 \mathrm{mg}, 0.27 \mathrm{mmol})$, Xantphos (311 mg, 0.54 mmol) and N,N-Diisopropylethylamine $(3.1 \mathrm{~mL}, 17.7 \mathrm{mmol})$. The reaction mixture was flushed with nitrogen and stirred at $120{ }^{\circ} \mathrm{C}$ overnight. The crude mixture was concentrated to dryness and the crude residue was purified by flash chromatography on $\mathrm{SiO}_{2}$ to afford the title compound 36 (2.5 g, 76\% yield). LC-MS: m/z=371 [M+H]+

Step c): 5-Amino-6-(3,3,3-trifluoro-2-hydroxy-propylcarbamoyl)-pyridine-3-sulfonyl chloride (37):

To a solution of compound $36(371 \mathrm{mg}, 1 \mathrm{mmol})$ in a mixture of $\mathrm{AcOH}(150 \mu \mathrm{L}), \mathrm{H}_{2} \mathrm{O}(250$ $\mu \mathrm{L})$ and $\mathrm{CH}_{3} \mathrm{CN}(3.5 \mathrm{~mL})$ was added portion wise 1,3-dichloro-5,5-dimethylhydantoin (394 
$\mathrm{mg}, 2 \mathrm{mmol}$ ) at $0{ }^{\circ} \mathrm{C}$. The reaction mixture was stirred for $10 \mathrm{~min}$ and used as such in next step (sulphonamide formation).

\section{3-Amino-N-(3,3,3-trifluoro-2-hydroxy-propyl)-5-[[4-(trifluoromethoxy)-1-} piperidyl]sulfonyl]pyridine-2-carboxamide (20):<smiles>Nc1cc(S(=O)(=O)N2CCC(OC(F)(F)F)CC2)cnc1C(=O)NCC(O)C(F)(F)F</smiles>

Compound 37 (50 mg, $0.14 \mathrm{mmol})$ was taken up in acetonitrile $(0.57 \mathrm{~mL})$. 4,4difluoropiperidine (26 mg, $0.22 \mathrm{mmol})$ and $\mathrm{Et}_{3} \mathrm{~N}(80 \mu \mathrm{L}, 0.575 \mathrm{mmol})$ were then added. The reaction mixture was stirred at room temperature for $15 \mathrm{~h}$. The reaction mixture was diluted with water and extracted with EtOAc. The combined organic layers were then dried over $\mathrm{MgSO}_{4}$, concentrated and the crude residue was purified by preparative HPLC to afford the title compound 20 (12 mg, 19\% yield). 1H NMR (400 MHz, DMSO-d6) $\delta$ ppm $8.81(\mathrm{t}, 1 \mathrm{H})$, 8.01 (d, 1 H, d), 7.56 (d, 1 H), 7.26 (s br, 2 H), 6.49 (d, 1 H), 4.57 (m, 1 H), 4.23 (m, 1 H), 3.59 (m,1 H), 3.42 (m, 2 H), 3.28 (m, 1 H), 2.90 (m, 2 H), 2.00 (m, 2 H), 1.75 (m, 2 H). LC-MS: $\mathrm{m} / \mathrm{z}=481[\mathrm{M}+\mathrm{H}]^{+}$.

\section{HPLC traces of lead compounds 10 and 13}

2: UV Detector: TIC

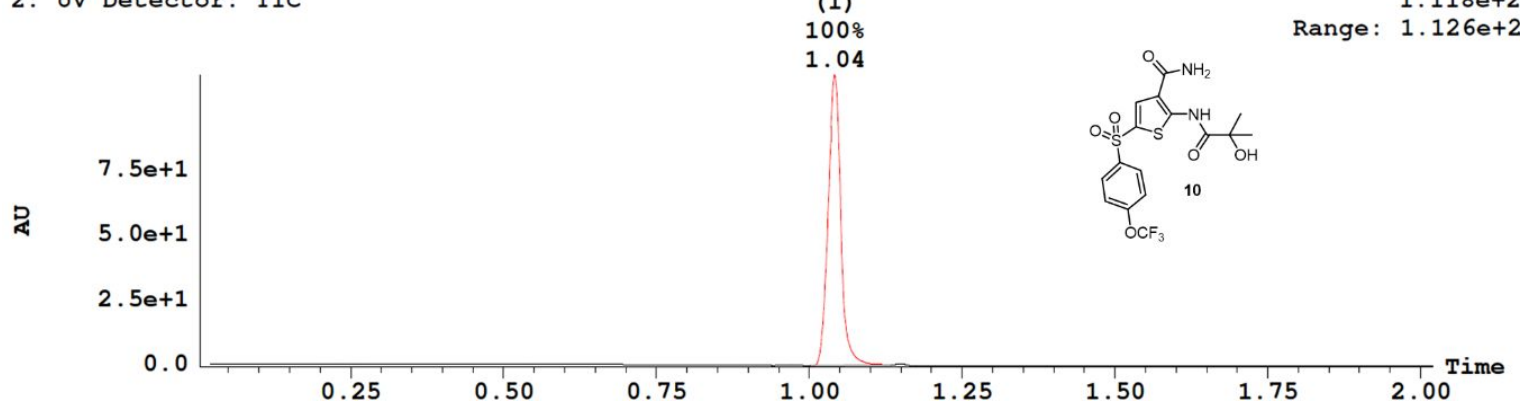

2: UV Detector: TIC
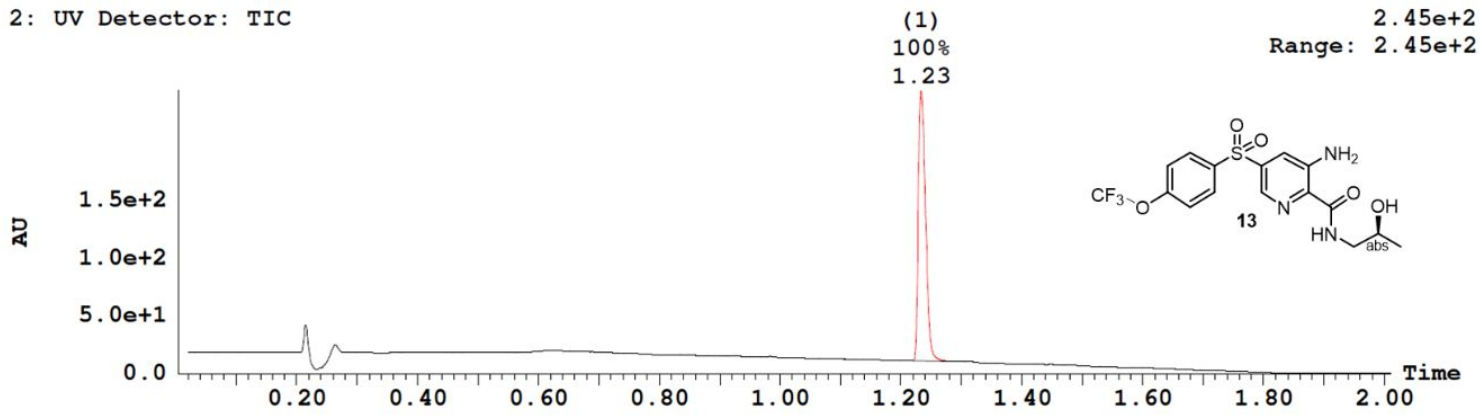